\title{
Development Aid and Human Capital Development in Nigeria: A Sector Level- Analysis
}

\section{Iyabo Adeola Olanrele ${ }^{1}$ Segun Subair Awode ${ }^{2 \star}$}

${ }^{1,2}$ Economic and Business Policy Department, Nigerian Institute of Social and Economic Research, Ibadan, Nigeria.

Email:adeyemiyabo@yahoo.com Tel:+2348066226531

Email: awodesegun@gmail.com Tel:+2348166757599

\section{Abstract}

Developing countries are generally faced with financial gap and budget constraints, and as such are dependent on aids to meet basic social and economic responsibilities. However, there are increasing concerns regarding the effectiveness of aid in developing countries, owing to worsening social and economic outcomes despite the huge amount of aid received from donor countries and institutions. This study therefore examines the effects of sector specific aid such as: health aid and education aid on life expectancy and primary school enrolment rate respectively in Nigeria, controlling for the influence of government expenditures on health and education. The Autoregressive Distributed Lag (ARDL) model was adopted with annual data from 1981 to 2017. Findings revealed that health aid is beneficial as it significantly increases life expectancy by about $0.03 \%$. Recurrent expenditure complemented health aid by increasing life expectancy by $0.03 \%$. However, education aid is detrimental to primary school enrolment as it reduces the rate by $0.07 \%$. Thus, it is concluded that education aid have not had the desired impact on education in Nigeria.

Keywords: Development aid, Human capital development, Government expenditures, Life expectancy, Primary school enrolment, ARDL, Nigeria.

JEL Classification: C10, F35, H50, H51, H52.

Citation | Iyabo Adeola Olanrele; Seoun Subair Awode (2020). Development Aid and Human Capital Development in Nigeria: A Sector Level-Analysis. Asian Journal of Economics and Empirical Research, 7(1): 25-35.

History:

Received: 19 November 2019

Revised: 23 December 2019

Accepted: 28 January 2020

Published: 26 February 2000

Licensed: This work is licensed under a Creative Commons Attribution 3.0 License (cc)

Publisher: Asian Online Journal Publishing Group
Acknowledgement: Both authors wish to acknowledge previous authors and scholars whose works were found useful to the study. Authors also thank the Central Bank of Nigeria, the World Bank and the Organisation for Economic Cooperation and Development whose databases were consulted to source the data used for the empirical analyses.

Funding: This study received no specific financial support.

Competing Interests: The authors declare that they have no conflict of interests.

Transparency: The authors confirm that the manuscript is an honest, accurate, and transparent account of the study was reported; that no vital features of the study have been omitted; and that any discrepancies from the study as planned have been explained.

Ethical: This study follows all ethical practices during writing.

\section{Contents}

1. Introduction

2. Stylized Facts on Development Aid and its Effectiveness on Human Capital Indicators

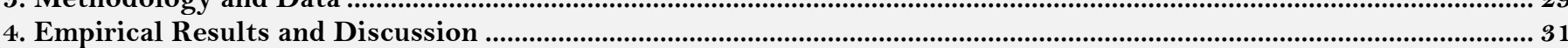

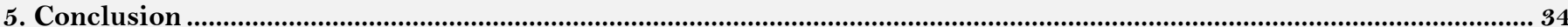

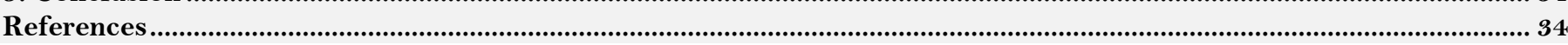




\section{Contribution of this paper to the literature}

This paper contributes to the literature by examining the impact of specific aid to the health and education sectors on life expectancy and primary school enrolment in Nigeria, rather than on overall economic growth which has been the focus of most studies on aid effectiveness in Nigeria.

\section{Introduction}

The financial gap/budget constraints made development aid indispensable in developing countries. Official Development Aid (ODA) for Development is meant to augment financial and technical assistance for social and economic development. Aid is expected to help less developed countries out of deep-rooted problems of under development. The development benefits accrue through improved and high human development, a healthier society, and a higher standard of living.

Nigeria ranked one among the top ten aid recipients in Africa. On the average, net Official Development Assistance (ODA) from all donors received in Nigeria grew from US\$ 301 million in the period 1970-97 to US\$ 2162 million in 2010-16. In 48 years period (1970-2016), 4.5 per cent share of ODA from all donors came to Nigeria. Commitment to the social sector was US\$ 1947 million in the period 2016. Using social indicator of education, Nigeria ranked fifth among the top ten ODA recipients in Africa in 2016. The total commitment of US\$ 209 million was made to education. In the health sector, the country ranked first, with a total of US $\$ 935$ million received in the same period.

Despite this huge assistance, there are growing concerns over the performance of key human capital development indicators of health and education. Education indicator measured by adult literacy revealed an average of 53.8 per cent literacy rate in the period 1991 to 2008. This translates to an illiteracy rate of above 40 per cent, which is phenomenal in a country with one of the largest education ODA received in Africa. Although school enrolment has increased over time, basic enrolment in primary education shows a net value of about 63 per cent with a record of highest number of out of school children, which stood at 10.5 million.

Access to basic health facilities like the Primary Health Care Facilities (PHF) remained a daunting challenge with long-term foreign finance in the country. Nigeria's ranking as the highest recipient of health ODA in Africa did not make a significant dent on key health indices like the infant mortality caused mostly by avoidable diseases like polio, measles, and malaria. The escalating incidence of maternal mortality equally cast aspersion on the effectiveness of ODA in spite of its growing magnitude, with a huge impact on average life expectancy rate in the country. For instance, from 289 per 100,000 persons in 2013, maternal mortality rose to 576 in 2013 (WDI, 2017). Further, the country has one of the highest records of under-five child mortality rate, after India and Pakistan. Evidence in Nigeria indicates 100 under-five mortality per 1000 live births, a situation at variance with foreign donors spending on health.

Various findings have emerged from analysing the effects of ODA on development. In specific terms, attention is paid to the literature addressing the role of aid in reducing the infant mortality rate. A study by Kotsadam, Østby, Rustad, Tollefsen, and Urdal (2018) empirically established that geographical proximity to active aid projects reduces infant mortality in Nigeria, especially among the less privileged group. The study adopted a subnational approach to ODA-infant mortality relationship. Also, evidence abounds that countries with an increase in the amount of health aid experience a more rapid decline in child mortality (Douzounet \& Urbain, 2015). The study was carried out with data from 94 developing countries, Nigeria inclusive. Through female education and governance channels, the study established that a $1 \%$ increase in health aid saves the lives of four children in over five years.

The conclusion reached is that the benefits of aid projects are location specific, such that biases arise if aid did not target those populations in greatest need. Health aid was revealed to have a statistically significant and positive effect on infant mortality rate in developing countries (Yousuf, 2012). Specifically, a doubling of aid leads to an approximately $1.3 \%$ reduction in infant mortality rates. Thus for an average aid recipient country, doubling per capita aid leads to a reduction of about 790 deaths per million live births in a particular year. However, the finding of Woubedle (2011) on aid and infant mortality in Africa was inconclusive. This is because the main determinants of infant mortality did not drive significant impact, which makes it difficult to make conclusions on the actual effect foreign aid has on infant mortality. Thus raising a concern for aid fungibility, a term describing whether aid resources in Africa are actually being used for their intended purposes or being switched by recipient countries (Álvarez, Borghi, Acharya, \& Vassall, 2016).

On the effectiveness of aid on education, Douzounet and Urbain (2015) used data for 34 African countries including Nigeria, to assess the effectiveness of aid and its efficiency on primary school completion rate. They found that higher aid to education significantly increases the primary school completion rate in Africa. Strong heterogeneity in the efficient use of aid among African countries was also found. In countries like Botswana, Togo, and Kenya, the distribution of efficiency scores was high while Burkina Faso, Niger and Rwanda has lowest efficiency scores, thus, suggesting an inefficient use of education aid. A positive correlation was found between aid and the initial level of education.

Studies abound in the literature on the impact of foreign aid on economic growth, health and education in both developed and developing countries (Afridi \& Ventelou, 2013; Birchler \& Michaelowa, 2016; Hsiao \& Emdin, 2015; Irfan \& Nehra, 2016; Kotsadam et al., 2018; Riddell \& Nino-Zarazua, 2016). Several empirical studies have investigated the impact of foreign aid on human capital development based on cross country analysis. However, there is dearth of empirical studies examining the impact of sector-specific ODA on human capital development in Nigeria. Birchler and Michaelowa (2016) notes that it is exciting to see the indirect effect of health ODA on economic growth, however, education and health outcomes represent important components of human capital development which could as well be a means to growth and development.

The question then remains whether ODA for human capital development is effective in Nigeria. Studies like Azarnert (2008); Staicu and Barbulescu (2017) have examined this relationship on health indicators such as life expectancy rate and fertility rate alone. Okon (2012) used the Human Development Index, which is a composite of 
health, education and living standard index. Other strands of literature empirically investigated the relationship between foreign aid and economic growth (Nwosu, 2018; Olanrele \& Ibrahim, 2015). Departing from these literatures, this study investigates the effects of foreign aids on human capital development indicators. The analysis is at a disaggregated level, such that life expectancy and primary school enrolment rates are specified as a function of foreign aid in separate models. The rationale is to be able to account for human capital development on a broader spectrum rather than the narrow measure of health or education alone. The subsequent sections are outlined as follows: section 2 presents some stylized facts on development aid and its effectiveness on human capital development in Nigeria. Section 3 contains the methodology. Section 4 gives the empirical results and discussion while section 5 concludes.

\section{Stylized Facts on Development Aid and Its Effectiveness on Human Capital Indicators}

\subsection{Stylized Facts on Development Aid}

This section discussed the trend of ODA flow in Nigeria, with emphasis on social sector that reflects the human capital development. A comparison was equally provided across the major aid recipients in Africa.

The total inflow of aid to Nigeria increased gradually from 1970 to 2016. In the forty-six years period (19702016), aid received in Nigeria grew by over 2000 per cent. There was a gradual increase from the 1970 s to 1990 s Figure 1. However, a sudden rise was observed during the 2000s, when total aid received reached US\$2,444 million from a modest value of US\$ 282 million in the 1990s. This development could simply be alluded to the renewed donor interest, especially in improving key development indicators and the return of civil rule in Nigeria in 1999. Another reason could be due to an increase in total ODA commitment to Africa, which is seen in the surge in the share of Nigeria's ODA received Figure 2. A decline was recorded in the period 2010 to 2016.

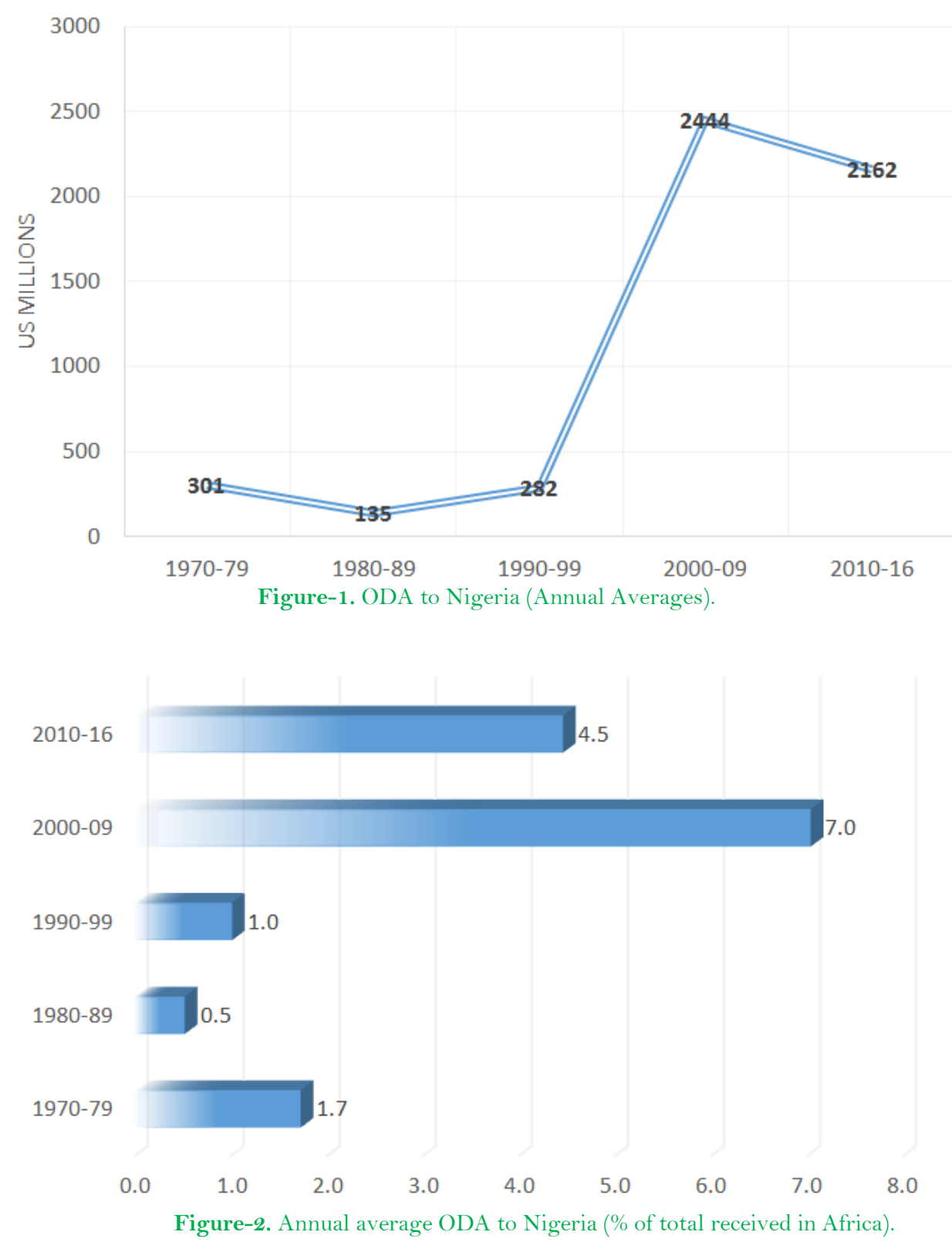

In 2016, more than half of the ODA went to the social sector (72\%). Increase in internal crisis, such as Boko Haram insurgencies and the farmer-herders conflicts, contributed to the significant aid of $13 \%$ received in the humanitarian sector Figure 3. Relative to other major aid recipients in Africa, Nigeria is the only country with more than 10\% ODA for humanitarian purposes after Ethiopia Figure 4. As shown in Figure 3 economic, multisector and the production sectors had $8 \%, 5 \%$ and $2 \%$ share in total ODA received in 2016. 


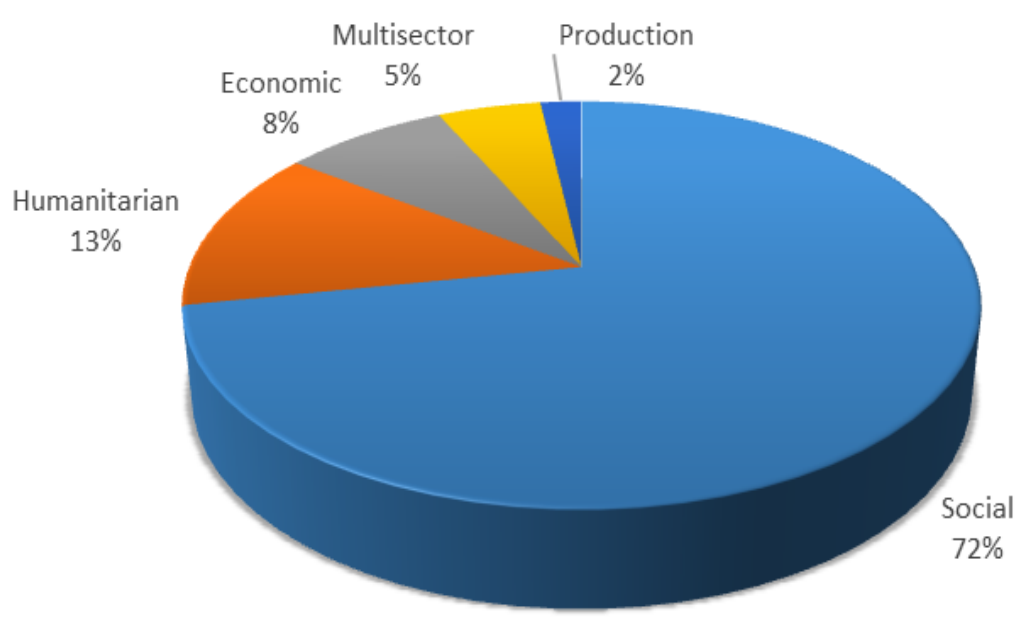

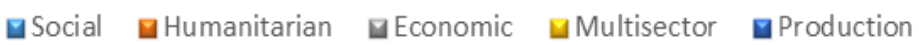
Figure-3. ODA by Sector in 2016 (\% of Total).

Some four sub-Saharan African countries and a North African country were the five largest recipients of aid in 2016. Donor expenditure on aid was mostly on social and economic sectors. Social aid, which had the largest share, was received by Nigeria, Tanzania, and Kenya Figure 4. The largest share of economic aid went to Egypt, then Ethiopia and Kenya. General programme aid got the least share of donation in Kenya and Ethiopia.

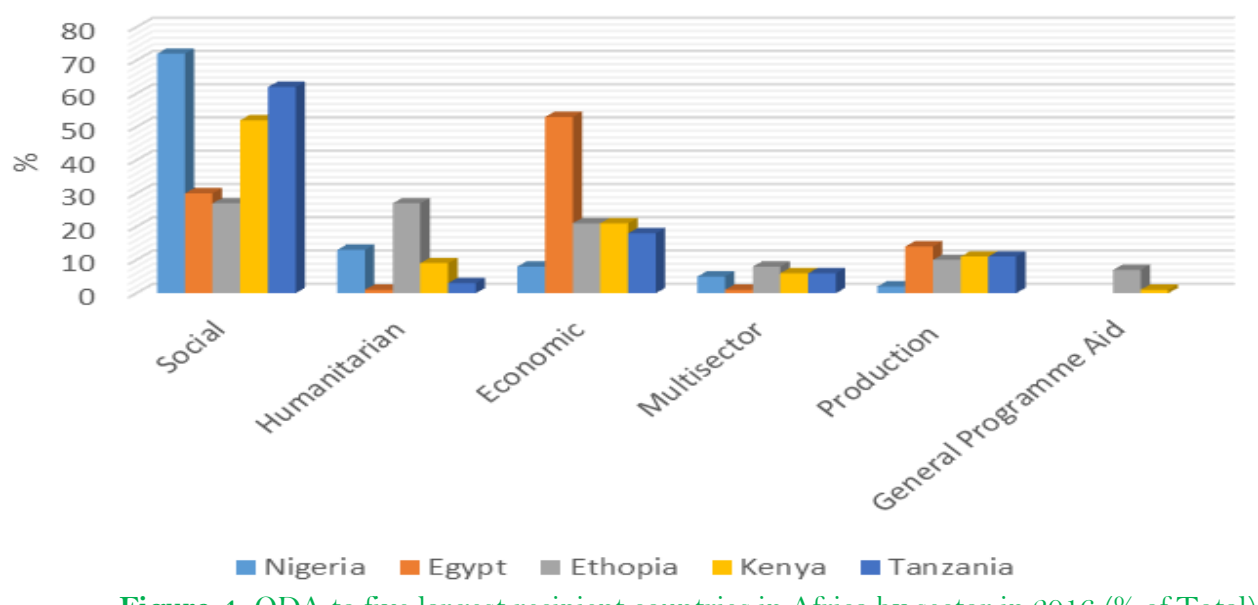

Figure-4. ODA to five largest recipient countries in Africa by sector in 2016 (\% of Total).

Breaking the sectors further, Figure 5 shows that health sector aid has the highest social sector ODA received in the period 2012 to 2016. Although there was a tremendous decline from US\$ 1,154 million in 2013 to US $\$ 680$ million in 2014, a sharp increase to the tune of US\$2,193 was recorded in 2015. Apparent is the fact that the education sector got the least aid among the two sub-sectors. In the analysis of the top 10 largest education aid recipients in Africa, Nigeria's position hovers around 4th and 9th in the period 2012 to 2016. Topping the list is Nigeria, which ranked 1st among the 10 largest health aid recipients in the same period, except in 2014 when Kenya got the largest health aid in Africa.

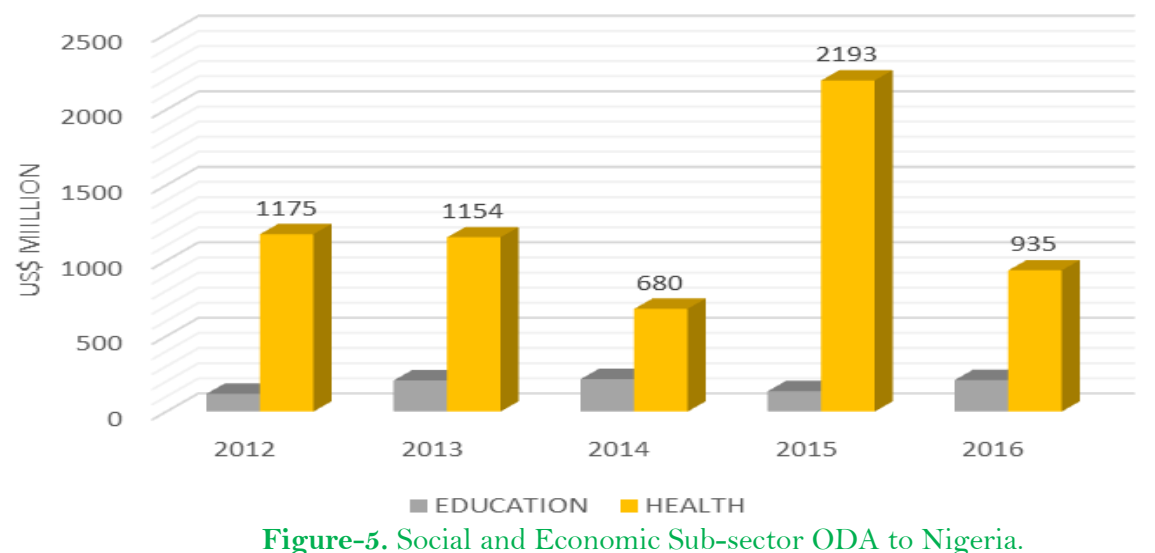

Summarily, aid received for development purposes is huge in Nigeria, and as such, aid is expected to make a meaningful contribution to key human capital development indicators in the country.

\subsection{Effectiveness of Aid on Human Capital Development}

Ascertaining the effectiveness of aid entails that the performance of the selected key development indicators is examined. The key indicator targeted by health aid is to ensure a reduction in the rate of infant mortality, which impact average life expectancy rate. Over the years there has been a gradual reduction in the rate of infant mortality vis-à-vis health aid Figure 6 . A decline of about $61 \%$ was recorded in the infant mortality rate in the space of 46 years (1970-2016). The decreasing rate cannot be accorded to health aid considering the pattern of 
movement exhibited. With aid and other factors outside the scope of this study, the incidence of infant mortality rate is relatively high at the present rate of more 60 per cent.

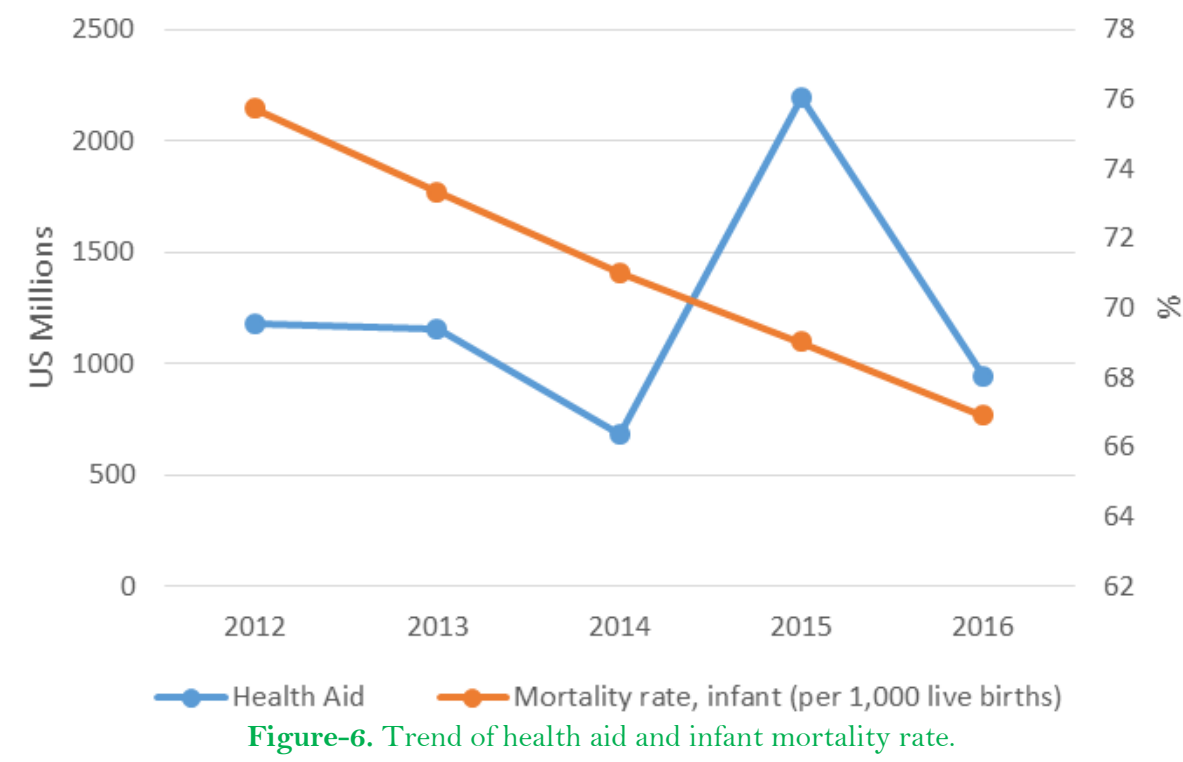

Being one of the highest education aid recipient countries in Africa, the number of children enrolled in the primary school is expected to increase, with a decreasing effect on the number of out of school children. The aim is to enhance human development through an increase in literacy rate and the country's overall productivity. As shown in Figure 7 the total enrolled population of the age group that officially corresponds to the primary school level was above 40 per cent in the period 1970 to 2016. The obvious challenge is the fact that the percentage of out-of-school children, in the same age group, was consistently above 30 per cent in the referenced period (World Development Indicator (WDI), 2018). In a proximate economy like South Africa, the number of out-of-school children for the referenced group has reduced by about 76 per cent from 35 per cent in 1970 to 8 per cent in 2015 . This explains the high rate of literacy in South Africa (average 88 per cent) compared to Nigeria's (47 per cent). With education aid mostly channeled to primary school education (OECD-DAC, 2015) the number of out of school children at this level is alarming.

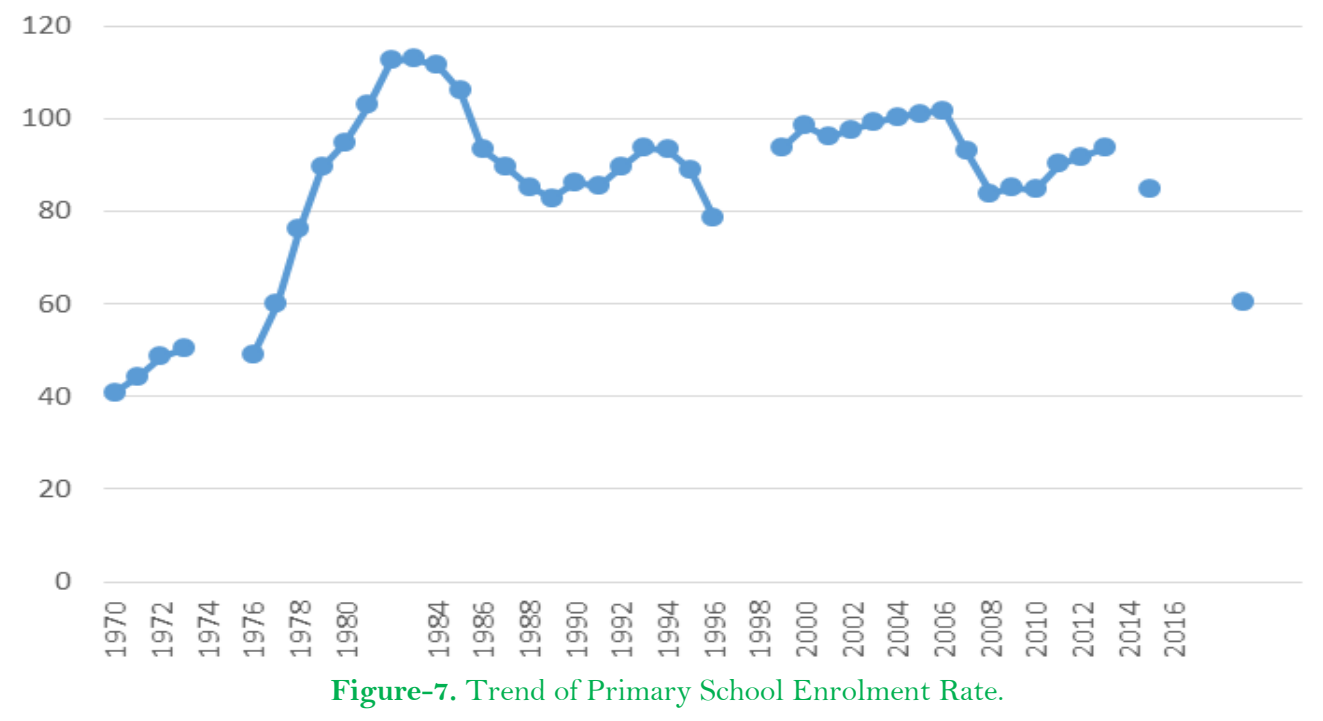

It is obvious from the foregoing discussion that aid has not brought about the desired development in Nigeria going by the performance of the selected development indicators, especially education outcomes. The challenge then is how to internally enhance national development in the presence of abundant resources.

\section{Methodology and Data}

\subsection{Methodology}

This section presents the methodology adopted for this study. It first presents a conceptual framework that shows the link between development aid and human development outcomes. It then presents the econometric model adopted for the empirical analysis of the impact of development aid on human capital development in Nigeria. 


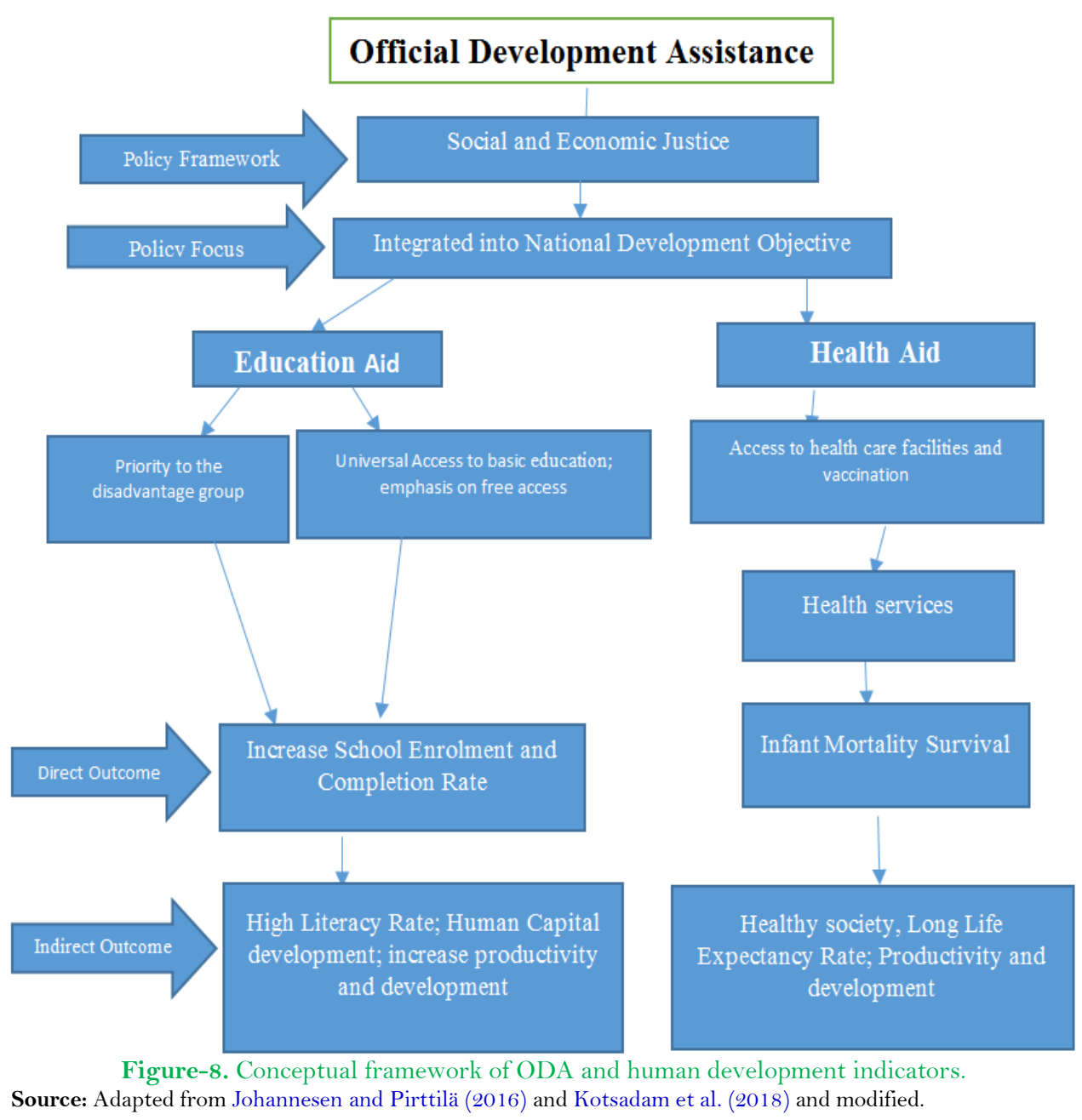

The underlying principle around the framework in Figure 8 is that development indicators are basic necessities that should be enjoyed by the citizenry irrespective of social or economic strata. Hence, where gaps exist, foreign development assistance is provided to support the policy focus of national governments in lifting individuals out of development quagmire. These external supports are justified in contexts where the government cannot meet their financial obligation due to limited finances or political will (Johannesen \& Pirttilä, 2016). The overarching aim is that various direct and indirect outcomes are achieved for overall economic development.

In line with the objective of this study which is to examine the human capital developmental outcomes of foreign aid in Nigeria and in line with the conceptual framework, the study modeled official development assistance as a determinant of the two components of human capital development; education and health in separate models. The study controlled for the impact of government expenditure on both education and health in the respective models since foreign aid helps recipient countries to augment domestic budgetary allocations for provision of basic needs (Johannesen \& Pirttilä, 2016; Liu, Fan, Chao, \& Eden, 2019). Therefore, the model for the study is specified below:

$$
H C D=f(O D A)
$$

Where: $H C D$ is human capital development and $O D A$ is official development assistance.

By controlling for the impact of government expenditure, the model becomes:

$$
H C D=f(O D A, G E X P)
$$

Disaggregating government expenditure into its capital and recurrent components

$$
H C D=f(O D A, C E X P, R E X P)
$$

In order to capture human capital development, the study made use of life expectancy ratio (following Mishra and Newhouse (2009)) and primary school enrolment rate (following Birchler and Michaelowa (2016)) as measures of health and education outcomes respectively. Furthermore, the study used sector-specific components of development assistance and government expenditures on health and education respectively. Hence, the two working models become:

$$
\begin{aligned}
& L E=f(H O D A, C E X P H, R E X P H) \\
& P S E=f(E O D A, C E X P E, R E X P E)
\end{aligned}
$$

By specifying the models in functional form:

$$
\begin{aligned}
& L E=\alpha_{o}+\alpha_{1} H O D A+\alpha_{2} C E X P H+\alpha_{3} R E X P H+\mu \\
& P S E=\alpha_{o}+\alpha_{1} E O D A+\alpha_{2} C E X P E+\alpha_{3} R E X P E+\mu
\end{aligned}
$$

A positive relationship is theoretically expected between the regressors and their respective regressands.

Following the model specification, this study uses the Autoregressive Distributed Lag (ARDL) technique to examine the relationship between foreign aids and human capital development in Nigeria from 1981 to 2017. The study estimates two models; the first examines the impact of sector-specific aids to the health sector on life expectancy, while the other examines the impact of educational aids on primary school enrolment rate. The study controlled for the impact of sector-specific government expenditure in the two models, which was disaggregated into capital and recurrent health and education expenditures. Hence, the econometric forms of the equations presented in Equations 6 and 7 are expressed in ARDL form to capture the short run and long run impacts of 
foreign aid on human capital development, in line with Pesaran, Shin, and Smith (2001); Pesaran., Shin, and Smith (1996) are expressed thus:

$$
\begin{aligned}
& \Delta \log \left(L E_{t}\right)=\beta_{0}+\beta_{1} \log \left(L E_{t-1}\right)+\beta_{2} \log \left(\text { HODA }_{t-1}\right)+\beta_{3} \log \left(\text { CEXPH }_{t-1}\right)+\beta_{4} \log \left(\text { REXPH }_{t-1}\right)+ \\
& +\sum_{i=1}^{p} \alpha_{1} \Delta\left(L E_{t-1}\right)+\sum_{j=0}^{q 1} \alpha_{2 j} \Delta\left(H O D A_{t-1}\right)+\sum_{j=0}^{q 2} \alpha_{3 j} \Delta \log \left(C E X P H_{t-1}\right)+\sum_{j=0}^{q 3} \alpha_{4 j} \Delta\left(\text { REXPH }_{t-1}\right)+\varepsilon_{t} \\
& \Delta \log \left(P S E_{t}\right)=\beta_{0}+\beta_{1} \log \left(P S E_{t-1}\right)+\beta_{2} \log \left(E O D A_{t-1}\right)+\beta_{3} \log \left(\text { CEXPE }_{t-1}\right)+\beta_{4} \log \left(\text { REXPE }_{t-1}\right)+ \\
& +\sum_{i=1}^{p} \alpha_{1} \Delta\left(P S E_{t-1}\right)+\sum_{j=0}^{q 1} \alpha_{2 j} \Delta\left(\text { EODA }_{t-1}\right)+\sum_{j=0}^{q 2} \alpha_{3 j} \Delta \log \left(\text { CEXPE }_{t-1}\right)+\sum_{j=0}^{q 3} \alpha_{4 j} \Delta\left(\text { REXPE }_{t-1}\right)+\varepsilon_{t}
\end{aligned}
$$

Where:

$\mathrm{LE}_{\mathrm{t}}=$ Life Expectancy at time $\mathrm{t}$.

$\mathrm{HODA}_{\mathrm{t}}=$ Official Development Assistance to Health sector at time t.

$\mathrm{CEXPH}_{\mathrm{t}}=$ Capital expenditure to Health sector at time $\mathrm{t}$.

$\mathrm{REXPH}_{\mathrm{t}}=$ Recurrent expenditure to Health sector at time $\mathrm{t}$.

$\mathrm{PSE}_{\mathrm{t}}=$ Primary school enrolment at time $\mathrm{t}$.

$\mathrm{EODA}_{\mathrm{t}}=$ Official Development Assistance to Education sector at time $\mathrm{t}$.

$\mathrm{CEXPE}_{\mathrm{t}}=$ Capital expenditure to Education sector at time $\mathrm{t}$.

REXPE $_{t}=$ Recurrent expenditure to Education sector at time $t$.

$\beta_{0}=$ Constant term.

$\beta_{\mathrm{i}}$ and $\alpha_{\mathrm{i}}($ where $\mathrm{i}=1-4)=$ Parameter estimates.

$\Delta=$ Lag Operator Term.

$(\mathrm{p}, \mathrm{q})=$ Lag length of the dependent and independent variables respectively.

$\varepsilon_{\mathrm{t}}=$ Error Term at time $\mathrm{t}$.

We expect, a priori that $\alpha_{\mathrm{i}}$ and $\beta_{\mathrm{i}}>0$.

\subsection{Data}

The data needs for the study were gotten from three sources. The study employed annual secondary time series data from 1981 to 2017 sourced from Central Bank of Nigeria (CBN) Annual Statistical Bulletin, World Development Indicators and Organisation for Economic Co-operation and Development Statistical Database. Specifically, data on government expenditures (capital \& recurrent) were gotten from CBN Annual Statistical Bulletin, life expectancy and primary school enrolment rates were gotten from World Development Indicators while data on official development assistance (ODA) were sourced from OECD statistical database. Due to different units of measurements, the study made use of the logged values of all the variables in the series. Table 1 indicates the summary of the variables, their definitions, measurement units and source of data.

\begin{tabular}{l|l|l|l}
\hline Variables & Definition & Measurement (Unit) & Source \\
\hline Life Expectancy & $\begin{array}{l}\text { The average number of years an } \\
\text { individual is expected to live. }\end{array}$ & $\begin{array}{l}\text { Total life expectancy at birth } \\
\text { (Years) }\end{array}$ & WDI \\
\hline $\begin{array}{l}\text { Primary School } \\
\text { Enrolment Rate }\end{array}$ & $\begin{array}{l}\text { Percentage of children who are of } \\
\text { official primary school age and are } \\
\text { enrolled in primary school to the total } \\
\text { population of children of the official } \\
\text { primary school age. }\end{array}$ & $\begin{array}{l}\text { Net primary school enrolment } \\
\%\end{array}$ & WDI \\
\hline $\begin{array}{l}\text { Official Development } \\
\text { Edsistance (Health \& }\end{array}$ & $\begin{array}{l}\text { Financial aid given by foreign } \\
\text { governments and agencies to spur } \\
\text { development in Nigeria's health and } \\
\text { education sector. }\end{array}$ & $\begin{array}{l}\text { Total official donors' } \\
\text { disbursement to health and } \\
\text { education (USD millions) }\end{array}$ & OECD \\
\hline $\begin{array}{l}\text { Capital Expenditures } \\
\text { (Health \& Education) }\end{array}$ & $\begin{array}{l}\text { Government expenses on non- } \\
\text { financial assets e.g. infrastructures. }\end{array}$ & $\begin{array}{l}\text { Federal government capital } \\
\text { expenditures: Education and } \\
\text { and }\end{array}$ & CBN \\
\hline $\begin{array}{l}\text { Recurrent Expenditures } \\
\text { (Health \& Education) }\end{array}$ & $\begin{array}{l}\text { Government expenses on salaries and } \\
\text { overheads. }\end{array}$ & $\begin{array}{l}\text { Federal government recurrent } \\
\text { expenditures: Education and } \\
\text { Health (N' Billion) }\end{array}$ & CBN \\
\hline
\end{tabular}

\section{Empirical Results and Discussion}

\subsection{Introduction}

In this section, the empirical results of the study are discussed. The section begins with pre-estimation testing of the descriptive statistics and the unit root test analysis. The subsequent part of the section centres on the estimates of short and long run models as well as post-estimation diagnostic tests.

\subsection{Descriptive Analysis}

Table 2 shows the statistical properties of the selected variables. The skewness of the data series indicates that primary school enrolment showed an asymmetric or non-normal data distribution as the series relatively deviates from normality maintaining negative skewness, while others series are positively skewed. The kurtosis statistic shows that all the series are platykurtic in nature except primary school enrolment and recurrent expenditure on health which are leptokurtic and mesokurtic respectively. Also,the Jarque-Bera test is a test of normality with its null hypothesis being that the series under consideration is normally distributed. Based on our results using the Pvalues associated with the Jarque-Bera statistics, capital expenditure on health, education ODA and primary school enrolment are normally distributed while others are not. 


\begin{tabular}{c|c|c|c|c|c|c|c}
\hline \multicolumn{1}{c}{ Table-2. Descriptive statistics. } & REXPE & REXPH \\
\hline Variables & CEXPH & EODA & HODA & LE & PSE & REXP \\
\hline Mean & 49.03357 & 15720.34 & 11068.63 & 47.91595 & 92.33798 & 101.3627 & 59.05597 \\
\hline Median & 23.36560 & 12283.24 & 6428.560 & 46.12500 & 92.03793 & 39.88260 & 15.21808 \\
\hline Maximum & 167.6555 & 30299.08 & 33019.00 & 53.86633 & 113.0465 & 403.9571 & 257.7000 \\
\hline Minimum & 0.237600 & 5112.140 & 2601.780 & 45.63500 & 64.73919 & 0.162154 & 0.041315 \\
\hline Std. Dev. & 56.82478 & 7600.551 & 8815.425 & 2.680016 & 10.30280 & 134.5181 & 82.98504 \\
\hline Skewness & 0.879647 & 0.522199 & 1.062673 & 0.978804 & -0.102848 & 1.183198 & 1.269280 \\
\hline Kurtosis & 2.318879 & 1.789516 & 2.752844 & 2.425540 & 3.513886 & 2.875871 & 3.133389 \\
\hline Jarque-Bera & 5.486852 & 3.940558 & 7.058026 & 6.416775 & 0.472351 & 8.656823 & 9.962366 \\
\hline Probability & 0.064350 & 0.139418 & 0.029334 & 0.040422 & 0.789642 & 0.013188 & 0.006866 \\
\hline Observations & 37 & 37 & 37 & 37 & 37 & 37 & 37 \\
\hline & & & & & &
\end{tabular}

\subsection{Unit Root Test Analysis}

Table 3 details the summary results of the unit root test conducted on individual series using the Augmented Dickey-Fuller (ADF) stationary test. From the results, all the series are stationary at first difference, implying that they are integrated of order 1, which informs the usage of the Autoregressive Distributed Lag (ARDL) estimation technique which allows for a maximum order of integration of 1, following (Raza, Shahzad, Tiwari, \& Shahbaz, 2016).

Table-3. Summary of Unit root test results.

\begin{tabular}{c|c|c|c|c|c|c|c}
\hline Variable & \multicolumn{3}{|c|}{ Level } & \multicolumn{3}{c|}{ First Difference } & I (d) \\
\hline & None & Constant & $\begin{array}{c}\text { Constant } \\
\text { and Trend }\end{array}$ & None & Constant & $\begin{array}{c}\text { Constant } \\
\text { and Trend }\end{array}$ & \\
\hline$P S E$ & -0.6646 & $-3.2893^{*}$ & -2.1956 & $-5.0723^{*}$ & $-5.0574^{*}$ & $-5.0135^{*}$ & $\mathrm{I}(1)$ \\
\hline$E O D A$ & 1.7548 & -0.2162 & -1.6724 & $-5.3795^{*}$ & $-6.0508^{*}$ & $-5.9782^{*}$ & $\mathrm{I}(1)$ \\
\hline$C E X P E$ & -0.0469 & -0.8963 & -2.9821 & $-5.9342^{*}$ & $-6.0151^{*}$ & -5.9259 & $\mathrm{I}(1)$ \\
\hline$R E X P E$ & 1.8928 & 0.8762 & -1.2854 & $-4.6511^{*}$ & $-5.1005^{*}$ & $-5.4994^{*}$ & $\mathrm{I}(1)$ \\
\hline LE & 0.6123 & -1.1871 & $-7.8324^{*}$ & -1.3941 & $-3.8139^{*}$ & $-4.2847^{*}$ & $\mathrm{I}(1)$ \\
\hline HODA & 2.5331 & 0.8481 & -0.7984 & $-2.4051^{*}$ & -2.5546 & $-8.5093^{*}$ & $\mathrm{I}(1)$ \\
\hline CEXPH & -0.0469 & -0.8963 & -2.9821 & $-5.9342^{*}$ & $-6.0151^{*}$ & -5.9259 & $\mathrm{I}(1)$ \\
\hline REXPH & 1.6448 & 0.7474 & -1.3305 & $-7.4212^{*}$ & $-6.1724^{*}$ & $-7.4641^{*}$ & $\mathrm{I}(1)$ \\
\hline 5\% Critical Values & -1.9507 & -2.9484 & -3.5443 & -1.9507 & -2.9484 & -3.5443 & \\
\hline Note: * indicates significance at $5 \%$ level & & & & & &
\end{tabular}

Note: * indicates significance at $5 \%$ level.

\subsection{Bound Testing Analysis}

The bound test result as displayed in Figure 4 showed that the computed statistics exceeds both the lower bound and upper bound in the two models. Based on the computed statistics and critical values provided, we can conclude that there is co-integration among the series.

Table-4. Bound test for co-integration

\begin{tabular}{|c|c|c|c|c|c|c|}
\hline \multicolumn{7}{|c|}{ Bounds test for co-integration } \\
\hline \multicolumn{3}{|c|}{ Health Aid Model } & \multicolumn{4}{|c|}{ Education Aid Model } \\
\hline Test Statistic & Value & $\bar{K}$ & Test S & istic & Value & $\bar{K}$ \\
\hline F-statistic & 25.31 & 3 & F-st: & & 7.32 & 3 \\
\hline \multicolumn{3}{|c|}{ Critical Value Bounds } & \multicolumn{4}{|c|}{ Critical Value Bounds } \\
\hline Significance & Io Bound & I1 Bound & Significance & Io Bound & \multicolumn{2}{|c|}{ I1 Bound } \\
\hline $10 \%$ & 2.72 & 3.77 & $10 \%$ & 2.72 & \multicolumn{2}{|c|}{3.77} \\
\hline $5 \%$ & 3.23 & 4.35 & $5 \%$ & 3.23 & \multicolumn{2}{|c|}{4.35} \\
\hline $1 \%$ & 4.29 & 5.61 & $1 \%$ & 4.29 & \multicolumn{2}{|c|}{5.61} \\
\hline
\end{tabular}

\subsection{Effect of Health Aid on Life Expectancy Rate}

Table 5 details the short-run and long-run result of the impact of health ODA on life expectancy rate in Nigeria. The results showed that the major independent variable, health ODA has positive impact on life expectancy rate in both the short run and long run. However, while the short run impact is not significant, the long run impact is significant at 5 per cent level. Specifically, a per cent increase in health aid increases life expectancy rate by about 0.03 per cent. This implies that the focus of health ODA to Nigeria is more long-run oriented and forward-looking rather than satisfying short-term health needs. The result justifies the effectiveness of developmental schemes and programs of foreign donors in Nigeria's health sector which has drastically increased access to infant immunization, thereby reducing mortality rate, and life expectancy rate in the country. By reporting a positive link between health ODA and health outcomes, this result agrees with the findings of Hsiao and Emdin (2015), Afridi and Ventelou (2013) and Kotsadam et al. (2018) but contrasts the findings of Irfan and Nehra (2016).

Also, the result showed that government capital expenditure on health in Nigeria has negative impact on life expectancy rate both in the short run and long run. Like the health ODA, its short run impact is not significant but the long run impact is significant at 5 per cent level. This result could be explained on the grounds that in the face of increasing health ODA, government's own resources have been continually channelled to other areas of priority as the government deems fit, hence the negative effect of capital expenditure on life expectancy.

Furthermore, the result showed that government recurrent expenditure on health has significant positive impact on life expectancy in Nigeria both in the short run and in the long run, with a larger magnitude in the long 
run. This implies that government recurrent expenditure in the health sector has contributed meaningfully to enhancing life expectancy in Nigeria, and as such a complement to health aid.

The result showed that the error correction term is negative and significant, thus justifying the long run relationship established among the variables. It indicates that the system is able to adjust to long run equilibrium position at 3 per cent speed of adjustment.

Table-5. Long and short run estimates of health aid model.

\begin{tabular}{|c|c|c|c|c|}
\hline \multicolumn{5}{|c|}{ Dependent Variable: $L O G(L E)$} \\
\hline Variable & Coefficient & Std. Error & t-Statistic & Prob. \\
\hline \multicolumn{5}{|c|}{ Long Run Coefficients } \\
\hline LOG(HODA) & 0.026700 & 0.011350 & 2.352363 & 0.0265 \\
\hline LOG(CEXPH) & -0.022455 & 0.009469 & -2.371508 & 0.0254 \\
\hline LOG(REXPH) & 0.033763 & 0.007903 & 4.272115 & 0.0002 \\
\hline $\mathrm{C}$ & 3.638690 & 0.104928 & 34.678078 & 0.0000 \\
\hline \multicolumn{5}{|c|}{ Short Run Coefficients } \\
\hline DLOG(LE(-1)) & 0.871485 & 0.043848 & 19.875215 & 0.0000 \\
\hline DLOG(HODA) & 0.000847 & 0.000515 & 1.643276 & 0.1124 \\
\hline DLOG(CEXPH) & -0.000276 & 0.000187 & -1.479959 & 0.1509 \\
\hline DLOG(REXPH) & 0.000380 & 0.000143 & 2.653548 & 0.0134 \\
\hline DLOG(REXPH(-1)) & -0.000260 & 0.000122 & -2.135807 & 0.0423 \\
\hline CointEq(-1) & -0.031718 & 0.006877 & -4.611895 & 0.0001 \\
\hline
\end{tabular}

\subsection{Effect of Education Aid on Primary School Enrolment Rate}

Table 6 presents the results of the short run and long run impact of education ODA on primary school enrolment in Nigeria. The result revealed that the variable of major interest, education aid, has positive impact on primary school enrolment in the short-run but with a long run negative impact, although both are not statistically significant at five per cent. Also, government capital expenditure has a short run negative impact on primary school enrolment but a positive impact in the long run, with neither being statistically significant at five per cent level. Furthermore, government recurrent expenditure has a positive but non-significant impact on primary school enrolment while its long-run impact is insignificantly negative. The implication of this result is that education aid and government expenditure on education has not had desired outcome on primary school enrolment in Nigeria. This result points to allocative inefficiency or gross mismanagement and diversion of aids and funds, or both. This is not surprising, as the country boasts of the highest number of out of school children in the world, despite increasing budgetary allocation to education and being one of the top recipients of education ODA in Africa. The result therefore confirms the ineffectiveness of foreign aid whose aim is to enhance human capital development through an increase in literacy rate and the country's overall productivity. This result opposes the findings of Birchler and Michaelowa (2016) and Riddell and Nino-Zarazua (2016) who both found positive link between education ODA and school enrolment rates in selected developing countries.

The result showed a negative and significant coefficient of the error correction term, indicating that the series exhibit a convergence to long run equilibrium at approximately 89 per cent speed of adjustment.

Table-6. Long and short run estimates of education aid model.

\begin{tabular}{|c|c|c|c|c|}
\hline \multicolumn{5}{|c|}{ Dependent Variable: LOG(PSE) } \\
\hline Variable & Coefficient & Std. Error & t-Statistic & Prob. \\
\hline \multicolumn{5}{|c|}{ Long Run Coefficients } \\
\hline LOG(CEXPE) & 0.043775 & 0.039810 & 1.099618 & 0.2860 \\
\hline LOG(EODA) & -0.068323 & 0.065699 & -1.039938 & 0.3121 \\
\hline LOG(REXPE) & -0.026174 & 0.031791 & -0.823306 & 0.4211 \\
\hline $\mathrm{C}$ & 5.117431 & 0.605954 & 8.445253 & 0.0000 \\
\hline \multicolumn{5}{|c|}{ Short Run Coefficients } \\
\hline $\mathrm{DLOG}(\mathrm{PSE}(-1))$ & 0.524485 & 0.173325 & 3.026031 & 0.0073 \\
\hline DLOG(PSE(-2)) & 0.441879 & 0.187281 & 2.359444 & 0.0298 \\
\hline DLOG(CEXPE) & -0.020886 & 0.033142 & -0.630190 & 0.5365 \\
\hline $\operatorname{DLOG}(\mathrm{CEXPE}(-1))$ & 0.005807 & 0.031254 & 0.185806 & 0.8547 \\
\hline DLOG $(\mathrm{CEXPE}(-2))$ & 0.019495 & 0.028118 & 0.693307 & 0.4970 \\
\hline DLOG(CEXPE(-3)) & -0.071673 & 0.024658 & -2.906713 & 0.0094 \\
\hline DLOG(EODA) & 0.195996 & 0.106883 & 1.833742 & 0.0833 \\
\hline $\operatorname{DLOG}(\operatorname{EODA}(-1))$ & 0.070350 & 0.140935 & 0.499162 & 0.6237 \\
\hline $\operatorname{DLOG}(\operatorname{EODA}(-2))$ & 0.161997 & 0.103092 & 1.571390 & 0.1335 \\
\hline DLOG(REXPE) & 0.017542 & 0.022986 & 0.763166 & 0.4553 \\
\hline CointEq $(-1)$ & -0.890500 & 0.169753 & -5.245865 & 0.0001 \\
\hline
\end{tabular}

\subsection{Diagnostic Test Results}

In addition to the regression estimates, the study conducted some diagnostic residual tests which include Breusch-Godfrey Serial Correlation LM and Heteroskedasticity ARCH tests. In Table 7, the F-statistics of the serial correlation tests in the models were insignificant suggesting the absence of serial correlation in the residual of the regression estimates. The F-statistics of the Heteroskedasticity ARCH test was also insignificant confirming that the residual of the models were homoscedastic. The implication is that the regression estimates were appropriately estimated. 


\begin{tabular}{|c|c|c|}
\hline \multicolumn{3}{|l|}{ Health Aid Model } \\
\hline Diagnostics & Statistics & Interpretation \\
\hline $\begin{array}{ll}\text { Serial Correlation (Breusch-Godfrey Serial } \\
\text { Correlation LM Test) }\end{array}$ & $\mathrm{F}_{\text {stat }}=2.743172(0.0843)$ & $\begin{array}{l}\text { No evidence of serial } \\
\text { correlation }\end{array}$ \\
\hline Heteroscedasticity (ARCH LM Test) & $\mathrm{F}_{\text {stat }}=0.395054(0.9132)$ & Residual is homoscedastic \\
\hline \multicolumn{3}{|l|}{ Education Aid Model } \\
\hline Diagnostics & Statistics & Interpretation \\
\hline $\begin{array}{ll}\text { Serial Correlation (Breusch-Godfrey } & \text { Serial } \\
\text { Correlation LM Test) } & \\
\end{array}$ & $\mathrm{F}_{\text {stat }}=2.072481(0.1604)$ & $\begin{array}{l}\text { No evidence of serial } \\
\text { correlation }\end{array}$ \\
\hline Heteroscedasticity (ARCH LM Test) & $\mathrm{F}_{\text {stat }}=1.470491(0.2164)$ & Residual is homoscedastic \\
\hline
\end{tabular}

Note: Figures in parenthesis are probability values.

\section{Conclusion}

The financial gap/budget constraints have made aid attractive to aid recipient nations, with the aim to facilitate a development agenda. As such, this study examines the performance of foreign development aid on development in Nigeria, with a particular interest on key human capital development indicators like life expectancy and the primary school enrolment rates as measures of health and education respectively. Empirical results from the study confirmed a long run positive and significant relation between health aid and life expectancy rate in Nigeria. Specifically, an increase in health aid engenders about 0.03 per cent increase in life expectancy rate. Increase in government expenditure was able to complement health aid in increasing the life expectancy rate, specifically the government recurrent expenditure. Surprisingly, national infrastructural expenditure, that is the capital expenditure, reduces the rate of life expectancy. These findings suggest that life expectancy rate has improved with health aid and the national recurrent expenditure playing significant role, thus, the effectiveness of health aid. Overdependence on foreign aid has its attendant consequent of stifling home grown development strategies, hence, government should increase infrastructure expenditure through public private partnership arrangement, which will help to provide and expand basic health care facilities for a healthier society.

On the other hand, education aid has a non-significant positive impact on life expectancy rate in the short run and a negative but non-significant impact in the long run. Likewise, both capital and recurrent expenditures had no significant impact on primary school enrolment rate in Nigeria. This outcome alludes to the fact that foreign aid on education is not effective in Nigeria, likewise, the national government expenditure. Hence, a structural change that could engender the desired national transformation of this key development indicator requires a collective national action where all stakeholders including donor agencies, development partners and the government work together to ensure effective aid use strictly for their intended purposes. Also, the Nigeria's government should work out effective strategies to increase the rate of primary school enrolment, which could be through an increase in education expenditure and a national law that stipulates all children within the primary school age bracket to be duly enrolled in schools while non-adhering parents gets punished accordingly.

\section{References}

Afridi, M. A., \& Ventelou, B. (2013). Impact of health aid in developing countries: The public vs. the private channels. Economic Modelling, 31(1), 759-765.

Álvarez, M. M., Borghi, J., Acharya, A., \& Vassall, A. (2016). Is development assistance for health fungible? Findings from a mixed methods case study in Tanzania. Social Science \& Medicine, 159, 161-169. Available at: https://doi.org/10.1016/j.socscimed.2016.05.006.

Azarnert, L. V. (2008). Foreign aid, fertility and human capital accumulation. Economics, 75(300), 766-781. Available at: https://doi.org/10.1111/j.1468-0335.2007.00661.x.

Birchler, K., \& Michaelowa, K. (2016). Making aid work for education in developing countries: An analysis of aid effectiveness for primary education coverage and quality. International Journal of Educational Development, 48, 37-52. Available at: https://doi.org/10.1016/j.ijedudev.2015.11.008.

Douzounet, M., \& Urbain, T. Y. (2015). How aid helps achieving MDGs in Africa: The case of primary education. Working Papers 201501, CERDI.

Hsiao, A. J., \& Emdin, C. A. (2015). The association between development assistance for health and malaria, HIV and tuberculosis mortality: A cross-national analysis. Journal of Hepidemiology and Global Health, 5(1), 41-48. Available at: https://doi.org/10.1016/j.jegh.2014.10.001.

Irfan, Z. B., \& Nehra, A. (2016). Analysing the aid effectiveness on the living standard: A check-up on Southeast Asian countries. Journal of Urban Management, 5(1), 23-31. Available at: https://doi.org/10.1016/j.jum.2016.07.001.

Johannesen, N., \& Pirttilä, J. (2016). Capital flight and development: An overview of concepts, methods, and data sources. WIDER Working Paper, 95.

Kotsadam, A., Østby, G., Rustad, S. A., Tollefsen, A. F., \& Urdal, H. (2018). Development aid and infant mortality. Micro-level evidence from Nigeria. World Development, 105, 59-69. Available at: https://doi.org/10.1016/j.worlddev.2017.12.022.

Liu, X., Fan, H., Chao, C.-C., \& Eden, S. (2019). Foreign aid, human capital acquisition and educated Unemployment: Fish or fishing. International Review of Economics $\Theta^{2}$ Finance, 64, 1-8. Available at: https://doi.org/10.1016/j.iref.2019.05.007.

Mishra, P., \& Newhouse, D. (2009). Does health aid matter? Journal of Health Economics, 28(4), 855-872. Available at: https://doi.org/10.1016/j.jhealeco.2009.05.004.

Nwosu, U. (2018). Nigeria's economic growth: Does foreign aid really matter? A Thesis Presented to the Department of Economics, The University of Sheffield of the Requirements for the Degree of Economics and Public Policy.

OECD-DAC. (2015). Development aid rises again in 2015, spending on refugees double. Organisation for Economic Co-operation and Development, Development Co-operation Directorate. Retrieved from: https://www.oecd.org/dac/development-aid-rises-againin-2015-spending-on-refugees-doubles.htm.

Okon, E. O. (2012). Five decades of development Aid to Nigeria: The impact on human development. Journal of Economics and Sustainable Development, 3(1), 32-43.

Olanrele, I. A., \& Ibrahim, T. M. (2015). Does developmental aid impact or impede on growth: Evidence from Nigeria. International Journal of Economics and Financial Issues, 5(1), 288-296.

Pesaran, M. H., Shin, Y., \& Smith, R. J. (2001). Bounds testing approaches to the analysis of level relationships. Journal of Applied Econometrics, 16(3), 289-326. Available at: https://doi.org/10.1002/jae.616.

Pesaran., M. H., Shin, Y., \& Smith, R. J. (1996). Testing the existence of a long-run relationship. Cambridge Working Papers in Economics 9622, Faculty of Economics, University of Cambridge.

Raza, N., Shahzad, S. J. H., Tiwari, A. K., \& Shahbaz, M. (2016). Asymmetric impact of gold, oil prices and their volatilities on stock prices of emerging markets. Resources Policy, 49, 290-301. Available at: https://doi.org/10.1016/j.resourpol.2016.06.011. 
Riddell, A., \& Nino-Zarazua, M. (2016). The effectiveness of foreign aid to education: What can be learned? International Journal of Educational Development, 48, 23-36. Available at: https://doi.org/10.1016/j.ijedudev.2015.11.013.

Staicu, G., \& Barbulescu, R. (2017). A study of the relationship between foreign aid and human development in Africa. International Development, 135-152. Available at: http://dx.doi.org/10.5772/67483.

World Development Indicator (WDI). (2018). World Bank.

Woubedle, A. (2011). Aid and the African dilemma: The effect offoreign aid on human development in Africa. A Thesis Submitted to the Faculty of the Graduate School of Arts and Sciences of Georgetown University of the Requirements for the Degree of Master of Public Policy.

Yousuf, A. S. (2012). Impact of health aid on infant mortality rate. A Dissertation Submitted to University of Nottingham. Retrieved from: https://mpra.ub.uni-muenchen.de/42945/1/MPRA_paper_42945.pdf. 